$\begin{array}{ll}\text { Volume } & : 04 \\ \text { Nomor } & : 03 \\ \text { Bulan } & : \text { September } \\ \text { Tahun } & : 2018 \\ \text { http } & : / / \text { ejurnal.pps.ung.ac.id/index.php/AKSARA/index }\end{array}$

\title{
Manajemen Administrasi Desa Dalam Peningkatan Pelayanan Aparatur Desa Di Kabupaten Gorontalo Utara
}

\author{
Novianty Djafri, Syamsu Qomar Badu \\ Universitas Negeri Gorontalo \\ noviantydjafri@gmail.com
}

\begin{abstract}
ABSTRAK
Peningkatan kinerja aparatur pemerintah semakin gencar dituntut Aparatur dalam aksi nyata gerakan melayani, dalam hal ini dalam Gerakan Nasional Revolusi Mental, mengingat pentingnya reformasi birokrasi aparatur di semua instansi, demikian juga untuk peran pemerintah Desa, sebagai pelayan publik, maka setiap aparatur desa dapat memenej, menata dan mengelola admnistrasi desa, dalam peningkatan kualitas layanan untuk masyarakatnya. Penelitian ini dilaksanakan di Kabupaten Gorontalo Utara, Kecamatan Anggrek. Adapun Tujuan Penelitian untuk mengetahui kinerja pelayanan aparatur pemerintah desa dalam memberikan pelayanan publik, melalui tertib admnistrasi kepada warga desa, yang terdiri dari 5 (Lima) Desa, yaitu; Desa Iloheluma, Langge, Popalo, Mootilango, Talanga, dan putiana. Metode yang digunakan adalah deskriptif kuantitatif, dimaksudkan dalam penyajian hasil penelitian dijabarkan secara kuantitatif dan dideskripsikan lebih fleksibel, agar dapat leluasa menggali dan mengkaji lebih spesifik sesuai dengan permasalahan penelitian ini. Informan yang ditetapkan adalah kepala desa, perangkat desa, badan permusyawaratan desa, Lembaga Pemberdayaan Masyarakat Desa, karang taruna, tokoh Agama, tokoh masyarakat desa dan masyarakat desa. Hasil penelitian menunjukkan bahwa dari ketiga indicator kinerja, yaitu; 1) produktivitas, belum cukup baik, (dapat dilihat dalam kurangnya memberikan pelayanan kepada masyarakat, dengan sub indikator disiplin kerja, etos kerja dan tanggungjawab kerja yang dijawab responden berada pada kategori rendah, yaitu 65\%). 2) Kualitas layanan sudah cukup baik (dapat ditunjukkan dengan adanya komunikasi, kecakapan/kehandalan, keramahan, dan ketepatan waktu aparat desa dalam melayani masyarakat, melalui tanggapan respon masyarakat berada pada kategori baik, yaitu 78\%). 3) Akuntabilitas dalam pelayanan dibidang administrasi untuk masyarakat, berada di kategori cukup baik, hal ini dilihat pada jawaban resoponden untuk integritas rendah, penerapan standar pelayanan dibidang admnistrasi kependudukan, belum cukup baik dilihat dari pelaksanaan aturan da norma serta etika pelayanan kepada masyarakat.
\end{abstract}

\section{Kata Kunci: Manajemen Administrasi Desa. Pelayanan Aparatur Desa}

\section{PENDAHULUAN}

Gorontalo Utara merupakan salah satu kabupaten di Provinsi Gorontalo yang terletak dibagian utara dari Provinsi Gorontalo dan memiliki jumlah Desa sebanyak 123 Desa dengan penduduk sebanyak 129.039 jiwa, dengan kecamatan Kwandang sebagai ibu kota kabupaten. Sebagai ibu kota kabupaten, maka kecamatan Kwandang menduduki posisi strategis sebagai pusat pemerintahan dan pusat pelayanan jasa. Adapun jumlah penduduk kecamatan Kwandang menurut data yang diperoleh pada tahun 2017 adalah 34.106 jiwa dengan luas wilayah yang mencapai $336.80 \mathrm{~km}^{2}$, yang terbagi atas 18 Desa.

Sebagai wilayah pusat pemerintahan dan pusat pelayanan jasa maka sudah sewajarnya dituntut kualitas dari sumber daya aparat maupun sumber daya masyarakat yang ada di kecamatan Kwandang dalam upaya meningkatkan kualitas hidup masyarakat sehingga secara mandiri dapat meningkatkan kesejahteraannya. Dalam upaya meningkatkan kualitas sumber daya manusia yang ada di kecamatan Kwandang, salah satu strategi yang dapat diterapkan 


$\begin{array}{ll}\text { Volume } & : 04 \\ \text { Nomor } & : 03 \\ \text { Bulan } & : \text { September } \\ \text { Tahun } & : 2018 \\ \text { http } & : / / \text { ejurnal.pps.ung.ac.id/index.php/AKSARA/index }\end{array}$

adalah dengan melakukan terobosan-terobosan dibidang teknologi informasi, yakni berupa bentuk pelayanan disegala bidang yang berbasis teknologi informasi

Aparatur pemerintah semakin di tuntut dalam Gerakan Nasional Revolusi Mental untuk aksi nyata gerakan melayani terhadap peningkatan pelayanan aparatur desa di kabupaten Gorontalo Utara.

Gerakan Indonesia Melayani (GIM), Bagian penting dari tindakan revolusi mental di Indonesia yang di amanatkan oleh Presiden Joko Widodo, dalam Gerakan Nasional Revolusi Mental (GNRM), pada tanggal 14 Agustus 2015, melalui Pidato Kenegaraan di Dewan Perwakilan Daerah. Gagasan indonesia melayani bermakna untuk menyiapkan mental masyarakat, khususnya sebagai pelaksana aparatur negara dapat mempertahankan lembaga pemerintahannya juga menjaga karakter bangsa Indonesia dalam peningkatan etos kerja pegawai, melalui pelayanan prima (Service Excelent), sehingga karakter bangsa Indonesia lebih meningkat dan sampai pada suatu daerah dan SKPD, untuk itu dalam permasalahan pelayanan di kantor pertanahan masih jauh dari pelayanan prima (service Excelent).

Menurut Tunggal; 2000 bahwa Kemampuan pelayanan dalam lembaga/organisasi dan pemerintah banyak di tentukan oleh pelayanan yang di berikan kepada pihak yang berkepentingan dengan lembaga/organisasi tersebut. Penilaian tentang pelayanan ini sangat penting terhadap pemaknaan yang berkepentingan memberi pelayanan, berdasarkan pada tingkat kebutuhan oleh pihak pemberi pelayanan kepada pihak penerima pelayanan. Untuk pelayanan yang baik dan benar instansi dalam hal ini kantor pertanahan berkewajiban untuk menjaga eksistensi sebuah lembaga dalam mengembangkan aktivitas kinerja pegawai untuk memenuhi kebutuhan masyarakat

\section{KAJIAN TEORI}

\section{Manajemen Administrasi Desa}

Menurut Handoko: (2001) Menejemen adalah merencanakan, mengorganisasikan, memimpin, dan mengendalikan (POAC). Fungsi Manajemen terdiri dari POAC, merupakan Gerakan tindakan simultan dan saling berhubungan, yang akan membawa pada peningkatan hasil kinerja. Penyelenggara admnistrasi merupakan Intensitas penerapan sikap dan perilaku yang bermutu merupakan filosofi untuk mengubah paradigma manajemen eksekutif lama yaitu dari sikap dan perilaku yang dilayani, menjadi manajemen eksekutif yang melayani publik secara berkualitas (prima/Excellent).

Dalam Konteks Administrasi Pemerintahan Desa, secara luas bisa disebut sebagai manajemen penyelenggaraan Pemerintahan dan Pembangunan Desa, yang meliputi Pengelolaan penyelenggaraan pemerintahan desa, mencakup perencanaan pemerintahan, pengorganisasian atau kelembagaan pemerintahan, penggunaan sumber-sumber daya, pelaksanaan urusan rumah tangga pemerintahan dan urusan pemerintahan umum, serta pengawasan penyelenggaraan pemerintahan berdasarkan kewenangan dalam bidang pemerintahan desa.

Secara umum manajemen pemerintahan desa mencakup beberapa aspek sebagaimana telah disebutkan diatas, antara lain: 1) Perencanaan Pemerintahan Desa. 2) Pengorganisasian kelembagaan pemerintahan desa. 3) Penggunaan sumber-sumber daya pemerintahan desa 4) Pengawasan penyelenggaraan pemerintahan desa.

Undang-Undang Nomor 6 Tahun 2014 tentang Desa, menyebutkan bahwa salah satu kewajiban pemerintah desa adalah menyelenggarakan tertib administrasi desa yang mampu berfungsi sebagai sumber data dan informasi dalam penyelenggaraan pemerintahan Desa, pelaksanaan pembangunan, pembinaan kemasyarakatan dan pemberdayaan masyarakat. "Pemerintahan desa yang baik dan bersih (good governance dan clean governance) harus selalu 


$\begin{array}{ll}\text { Volume } & : 04 \\ \text { Nomor } & : 03 \\ \text { Bulan } & : \text { September } \\ \text { Tahun } & : 2018 \\ \text { http } & : / / \text { ejurnal.pps.ung.ac.id/index.php/AKSARA/index }\end{array}$

melekat dalam penyelenggaraan pemerintahan Desa, baik dalam pelaksanaan tugas, fungsi, kewenangan, hak, dan kewajiban yang dimiliki oleh pemerintahan Desa". Berdasarkan Peraturan menteri dalam negeri Nomor 47 Tahun 2016 tentang Administrasi Pemerintahan Desa, disebutkan Pemerintahan Desa adalah keseluruhan proses kegiatan pencatatan data dan informasi mengenai Pemerintahan Desa pada Buku Register Desa, dan pengembangan buku register desa yang diperlukan serta menyelenggarakan pelaporan sesuai ketentuan perundangundangan. Jenis-Jenis Administrasi Pemerintahan Desa, sebagai berikut; 1) Administrasi Umum adalah pencatatan data dan informasi mengenai kegiatan pemerintahan Desa pada Buku Administrasi Umum. 2) Administrasi Penduduk adalah kegiatan pencatatan data dan informasi mengenai kependudukan pada Buku Administrasi Penduduk. 3) Administrasi Keuangan adalah kegiatan pencatatan data dan informasi mengenai pengelolaan keuangan Desa pada Buku Administrasi Keuangan. 4) Administrasi Pembangunan adalah kegiatan pencatatan data dan informasi pelaksanaan pembangunan dan pemberdayaan masyarakat pada Buku Administrasi Pembangunan. 5) Administrasi Lainnya antara lain meliputi; kegiatan Badan Permusyawaratan Desa dalam buku administrasi Badan Permusyawaratan Desa (BPD), kegiatan musyawarah Desa dalam buku musyawarah Desa, dan kegiatan Lembaga Kemasyarakatan Desa/Lembaga Adat dalam buku Lembaga Kemasyarakatan Desa/Lembaga Adat.

Berdasarkan penjelasan diatas, bahwa aparatur desa dalam pelaksanaan manajemen adminitrasi Desa, harus melalui produktivitas pelayanan; a) perencanaan program yang strategis sesuai dengan karakteristik masyarakat, b) keterlaksanaan penggunaan anggaran ransparansi keterlaksanaan dan pelaporan anggaran keuangan, pengembangan pegawai, dan program peningkatan kualitas. Manajemen kinerja memberi dasar bagi pengelolaan pegawai secara efektif dan memberi layanan bermutu bagi customer dan atau pengguna sebab semua orang bekerja dalam kapasitas penuh serta bergerak ke arah yang sama. Untuk menghasilkan kualitas kerja yang optimal, salah satu indikatornya akan dipengaruhi oleh sikap dan perilaku manajemen eksekutif (Mirriam Sjofyan Arif, dkk, 2005).

\section{Pelayanan Aparatur Desa.}

Menurut Tjiptono, (2007 : 120), memberikan pengertian jasa atau pelayanan sebagai berikut : "Jasa/pelayanan adalah kegiatan yang dapat didefinisikan secara tersendiri yang pada hakikatnya tidak teraba (intangibles), pemenuhan kebutuhan dan tidak harus terikat pada penjualan produk atau jasa yang lain. Untuk menghasilkan jasa mungkin perlu atau mungkin tidak diperlukan penggunaan benda yang nyata (tangibles). Akan tetapi, sekalipun penggunaan benda itu perlu namun tidak terdapat pemindahan hak milik atas benda itu perlu namun tidak terdapat pemindahan hak milik atas benda tersebut (pemilikan permanent). Pengertian pelayanan yang dikemukakan oleh Davidow, (dalam Lovelock, 1988 : 18), menyebutkan bahwa :

"Pelayanan adalah hal-hal yang jika diterapkan terhadap suatu produk akan meningkatkan daya atau nilai terhadap pelanggan (service is those thing which when added to a product, increase its utility or value to the customer). Lebih lanjut Lovelock (1988:19) menyebutkan pelayan yang baik membutuhkan instruktur pelayanan yang baik pula. Hal terpenting adalah membuat setiap orang dalam, organisasi pada kualitas".

Menurut Moenir, (1988), pelayanan adalah proses pemenuhan kebutuhan melalui aktivitas orang lain yang berlangsung secara terus menerus. Lebih lanjut Moenir mengemukakan bahwa layanan yang diperlukan manusia ada dua (2) jenis layanan yaitu fisik yang sifatnya pribadi sebagai manusia dan layanan administrasi yang diberikan orang lain selaku anggota organisasi (organisasi masyarakat atau negara). Pelayanan umum yang dilakukan oleh siapapun bentuknya tidak terlepas dari tiga (3) macam seperti yang 


$\begin{array}{ll}\text { Volume } & : 04 \\ \text { Nomor } & : 03 \\ \text { Bulan } & : \text { September } \\ \text { Tahun } & : 2018 \\ \text { http } & : / / \text { ejurnal.pps.ung.ac.id/index.php/AKSARA/index }\end{array}$

dikemukakan oleh Moenir, (1995 : 191-195), dalam Manajemen Pelayanan Umum yaitu : 1). Pelayanan dengan bentuk lisan; Pelayanan bentuk lisan dilakukan oleh petugas-petugas dibidang hubungan dengan masyarakat (HUMAS), bidang layanan informasi dan bidangbidang lain yang tugasnya memberikan penjelasan atau keterangan kepada siapapun yang memerlukan. 2. Pelayanan melalui tulisan. Pada dasarnya layanan melalui tulisan cukup efisien terutama layanan jarak jauh. Agar layanan dalam bentuk tulisan dapat memuaskan pihak yang dilayani, maka harus memperhatikan faktor kecepatan, baik dalam pengolahan masalah maupun dalam bentuk proses penyelesaiannya. 3. Pelayanan dalam bentuk perbuatan. Pada umumnya layanan dalam bentuk perbuatan $70-80 \%$ dilakukan oleh petugas-petugas tingkat menengah dan kebawah. Karena itu faktor keahlian dan keterampilan petugas tersebut sangat menentukan terhadap hasil perbuatan atau pekerjaan.

Berdasarkan penjelasan teori diatas maka dapat disimpulkan bahwa untuk kinerja pelayanan aparatur pemerintah desa dalam memberikan pelayanan publik, melalui tertib admnistrasi kepada warga masyarakat kecamatan anggrek Kabupaten Gorontalo Utara dapat disintesa pada; 1) Kualitas layanan 2) Akuntabilitas dalam pelayanan dibidang administrasi.

\section{METODE PENELITIAN}

Penelitian ini menggunakan metode Metode yang digunakan adalah deskriptif kuantitatif, dimaksudkan dalam penyajian hasil penelitian dijabarkan secara kuantitatif dan dideskripsikan lebih fleksibel, agar dapat leluasa menggali dan mengkaji lebih spesifik sesuai dengan permasalahan penelitian ini, dengan demikian bahwa kuantitatif yang bersifat deskriftif yang menggambarkan dan membahas tentang Manajemen Administrasi Desa Dalam Peningakatan Pelayanan Aparatur Desa Di Kabupaten Gorontalo Utara. Penelitian ini mendeskripsikan satu variabel yaitu Manajemen Administrasi Desa Dalam Peningakatan Pelayanan Aparatur Desa Di Kabupaten Gorontalo Utara. Secara konseptual mengkaji pengeloaan admnistrasi desa untuk melayani masyarakat pada akhirnya ditujukan untuk meningkatkan dan mengembangkan kinerja pelayanan aparat desa yang berkualitas, terprogram serta baik dalam akuntabilitas/yang teranggarkan dengan baik dan secara sistematik serta terencana untuk masyarakat Desa.

Populasi dalam penelitian ini adalah warga desa, yang terdiri dari 5 (Lima) Desa, yaitu; Desa Iloheluma, Langge, Popalo, Mootilango, Talanga, dan putiana. Kecamatan Anggrek. Kabupaten Gorontalo Utara, yang berjumlah 125 orang. Untuk penentuan besarnya sampel sejumlah masyarakat mengacu pada pendapat (Arikunto 2005:107) bahwa apabila subjek kurang dari 100 orang di ambil seluruhnya sehingga penelitian merupakan penelitian populasi. Selanjutnya jika jumlahnya besar dari 100 orang maka diambil 10-15\% atau 20-25\% atau lebih. Jumlah wakil masyarakat Kecamatan Anggrek berjumlah 125 orang. Dari populasi tersebut diambil $25 \%$ dari populasi sehingga jumlah sampelnya $25 \%$ x $125=31$ guru. Untuk mempermudah dalam memperoleh data yang mendukung penelitian ini, maka data yang diperoleh adalah melalui prosedur teknik angket serta dokumentasi, juga di dukung oleh data lapangan dari Informan yang ditetapkan adalah kepala desa, perangkat desa, badan permusyawaratan desa, Lembaga Pemberdayaan Masyarakat Desa, karang taruna, tokoh Agama, tokoh masyarakat desa dan masyarakat desa.

Teknik analisis data yang digunakan dalam penelitian ini adalah teknik analisis deskriptif kuantitatif, yaitu mendeskripsikan tentang kepemimpinan mutu kepala sekolah di SDN SeKecamatan Batudaa Pantai Kabupaten Gorontalo dengan menggunakan analisis persentase melalui tabel frekuensi (persentasi) dengan formulasi sebagai berikut :

$\mathrm{P}=\mathrm{f} / \mathrm{n} \times 100 \%$

Kemudian untuk mengklasifikasikannya digunakan teknik analisis sebagai berikut (Sugiyono, 2010:107): 
$\mathrm{Pr}=\mathrm{Sc} / \mathrm{Si} \times 100 \%$

Skor yang diperoleh untuk setiap indikator selanjutnya akan diklasifikasikan sebagai berikut (Arikunto \& Jabar, 2010:35):

\begin{tabular}{|l|l|}
\hline $\begin{array}{l}\text { Skor Presentase } \\
(\%)\end{array}$ & Klasifikasi \\
\hline $91-100$ & Sangat Baik \\
\hline $76-90$ & Baik \\
\hline $51-75$ & Cukup Baik \\
\hline$\leq 50$ & Tidak Baik \\
\hline
\end{tabular}

\section{HASIL DAN PEMBAHASAN}

Hasil

Hasil analisis ini berupa data kuantitatif dengan menggunakan analisis secara deskriptif dengan tujuan untuk mendeskripsikan tujuan yang akan dicapai dalam penelitian ini. Untuk mendapatkan gambaran mengenai kinerja pelayanan aparatur pemerintah desa dalam memberikan pelayanan publik, melalui tertib admnistrasi kepada warga desa, yang terdiri dari 5 (Lima) Desa, yaitu; Desa Iloheluma, Langge, Popalo, Mootilango, Talanga, dan putiana di Kecamatan Anggrek Kabupaten Gorontalo Utara maka data penelitian;

\section{Produktivitas Aparatur Desa}

Tabel 4.1. Perencanaan Program Yang Strategis Sesuai Dengan Karakteristik Masyarakat.

\begin{tabular}{|c|c|c|c|c|}
\hline Kualifikasi & $\begin{array}{l}\text { Bobot } \\
\text { skor }\end{array}$ & Frekuensi & Skor & Presentase \\
\hline $\begin{array}{l}\text { Sangat } \\
\text { Setuju }\end{array}$ & 4 & 20 & 80 & $64,5 \%$ \\
\hline Setuju & 3 & 11 & 33 & $35,5 \%$ \\
\hline Tidak Setuju & 2 & 0 & 0 & $0,0 \%$ \\
\hline $\begin{array}{l}\text { Sangat Tidak } \\
\text { Setuju }\end{array}$ & 1 & 0 & 0 & $0,0 \%$ \\
\hline \multicolumn{2}{|c|}{ Jumlah } & 31 & 113 & $100 \%$ \\
\hline
\end{tabular}

Berdasarkan Tabel 4.1 menunjukan bahwa perolehan persentase dari 31 responden diperoleh skor jawaban dengan rincian sebagai berikut: sebanyak 20 responden $(64,5 \%)$ menyatakan sangat setuju dan sebanyak 11 responden $(35,5 \%)$ menyatakan, dan tidak ada responden yang menyatakan tidak setuju dan sangat tidak setuju. Sehingga dapat disimpulkan bahwa perencanaan program aparatur desa selalu tidak terprogram adalah 64.55 atau dalam kategori cukup Baik.

Tabel 4.2. keterlaksanaan penggunaan anggaran ransparansi keterlaksanaan dan pelaporan anggaran keuangan, pengembangan pegawai, dan program peningkatan kualitas

\begin{tabular}{|l|l|l|l|l|}
\hline Kualifikasi & $\begin{array}{l}\text { Bobot } \\
\text { skor }\end{array}$ & Frekuensi & Skor & Presentase \\
\hline $\begin{array}{l}\text { Sangat } \\
\text { Setuju }\end{array}$ & 4 & 20 & 80 & $64,5 \%$ \\
\hline
\end{tabular}




$$
\begin{array}{ll}
\text { Volume } & : 04 \\
\text { Nomor } & : 03 \\
\text { Bulan } & : \text { September } \\
\text { Tahun } & : 2018 \\
\text { http } & : \text { //ejurnal.pps.ung.ac.id/index.php/AKSARA/index }
\end{array}
$$

\begin{tabular}{|l|l|l|l|l|} 
Setuju & 3 & 11 & 33 & $35,5 \%$ \\
\hline Tidak Setuju & 2 & 0 & 0 & $0,0 \%$ \\
\hline $\begin{array}{l}\text { Sangat Tidak } \\
\text { Setuju }\end{array}$ & 1 & 0 & 0 & $0,0 \%$ \\
\hline & Jumlah & 31 & 113 & $100 \%$ \\
\hline
\end{tabular}

Berdasarkan Tabel 4.2 menunjukan bahwa perolehan persentase dari 31 responden diperoleh skor jawaban dengan rincian sebagai berikut: sebanyak 20 responden $(64,5 \%)$ menyatakan sangat setuju dan sebanyak 11 responden $(35,5 \%)$ menyatakan, dan tidak ada responden yang menyatakan tidak setuju dan sangat tidak setuju. Sehingga dapat disimpulkan bahwa perencanaan program aparatur desa selalu tidak terprogram adalah 64.55 atau dalam kategori cukup baik.

\section{Pelayanan Aparatur Desa.}

Kinerja produktivitas pelayanan aparatur Desa; a) perencanaan program yang strategis sesuai dengan karakteristik masyarakat, b) keterlaksanaan penggunaan anggaran ransparansi keterlaksanaan dan pelaporan anggaran keuangan, pengembangan pegawai, dan program peningkatan kualitas.

1) Kualitas layanan

Tabel 4.3 Layanan dengan lisan

\begin{tabular}{|l|l|l|l|l|}
\hline Kualifikasi & $\begin{array}{l}\text { Bobot } \\
\text { skor }\end{array}$ & Frekuensi & Skor & Presentase \\
\hline Sangat Setuju & 4 & 23 & 92 & $74,2 \%$ \\
\hline Setuju & 3 & 8 & 24 & $25,8 \%$ \\
\hline Tidak Setuju & 2 & 0 & 0 & $0,00 \%$ \\
\hline $\begin{array}{l}\text { Sangat Tidak } \\
\text { Setuju }\end{array}$ & 1 & 0 & 0 & $0,00 \%$ \\
\hline Jumlah & & 13 & 116 & $100 \%$ \\
\hline
\end{tabular}

Berdasarkan Tabel 4.3 menunjukan bahwa perolehan persentase dari 31 responden diperoleh skor jawaban dengan rincian sebagai berikut: sebanyak 23 responden $(74,2 \%)$ menyatakan sangat setuju, dan sebanyak 8 responden $(25.8 \%)$ menyatakan setuju, serta tidak ada responden yang menyatakan tidak setuju dan sangat tidak setuju. Sehingga dapat disimpulkan bahwa layanan aparatur desa secara lisan memberikan kesempatan masyarakat dalam memberikan pelayanan yang baik pendapat adalah 77,55 atau dalam kategori baik.

Tabel 4.4 Layanan melalui tulisan

\begin{tabular}{|l|l|l|l|l|}
\hline Kualifikasi & $\begin{array}{l}\text { Bobot } \\
\text { skor }\end{array}$ & Frekuensi & Skor & Presentase \\
\hline Sangat Setuju & 4 & 23 & 92 & $74,2 \%$ \\
\hline Setuju & 3 & 8 & 24 & $25,8 \%$ \\
\hline Tidak Setuju & 2 & 0 & 0 & $0,00 \%$ \\
\hline Sangat Tidak Setuju & 1 & 0 & 0 & $0,00 \%$ \\
\hline Jumlah & & 31 & 116 & $100 \%$ \\
\hline
\end{tabular}




$\begin{array}{ll}\text { Volume } & : 04 \\ \text { Nomor } & : 03 \\ \text { Bulan } & : \text { September } \\ \text { Tahun } & : 2018 \\ \text { http } & : / / \text { ejurnal.pps.ung.ac.id/index.php/AKSARA/index }\end{array}$

Berdasarkan Tabel 4.4 menunjukan bahwa perolehan persentase dari 31 responden diperoleh skor jawaban dengan rincian sebagai berikut: sebanyak 23 responden $(74,2 \%)$ menyatakan sangat setuju, dan sebanyak 8 responden (25.8\%) menyatakan setuju, serta tidak ada responden yang menyatakan tidak setuju dan sangat tidak setuju. Sehingga dapat disimpulkan bahwa layanan adminitrasi desa melalui tulisan oleh aparatur desa memberikan petunjuk pelayanan kepada masyarakat adalah 77,55 atau dalam kategori baik.

Tabel 4.5 Layanan berupa petunjuk, informasi yang sejenisnya ditujukan kepada orang yang berkepentingan agar memudahkan mereka dalam berurusan dengan instansi dan lembaga.

\begin{tabular}{|l|l|l|l|l|}
\hline Kualifikasi & $\begin{array}{l}\text { Bobot } \\
\text { skor }\end{array}$ & Frekuensi & Skor & Presentase \\
\hline Sangat Setuju & 4 & 23 & 92 & $74,2 \%$ \\
\hline Setuju & 3 & 8 & 24 & $25,8 \%$ \\
\hline Tidak Setuju & 2 & 0 & 0 & $0,00 \%$ \\
\hline $\begin{array}{l}\text { Sangat Tidak } \\
\text { Setuju }\end{array}$ & 1 & 0 & 0 & $0,00 \%$ \\
\hline Jumlah & & 31 & 116 & $100 \%$ \\
\hline
\end{tabular}

Berdasarkan Tabel 4.5 menunjukan bahwa perolehan persentase dari 31 responden diperoleh skor jawaban dengan rincian sebagai berikut: sebanyak 23 responden $(74,2 \%)$ menyatakan sangat setuju, dan sebanyak 8 responden (25.8\%) menyatakan setuju, serta tidak ada responden yang menyatakan tidak setuju dan sangat tidak setuju. Sehingga dapat disimpulkan bahwa aparatur desa dalam layanan petunjuk dan informasi memberikan pelayanan kinerja pada bawahannya adalah 77,55 atau dalam kategori baik.

Tabel 4.6 Layanan berupa reaksi tertulis atau permohonan, keluhan pemberian dan lain sebagainya.

\begin{tabular}{|l|l|l|l|l|}
\hline Kualifikasi & $\begin{array}{l}\text { Bobot } \\
\text { skor }\end{array}$ & Frekuensi & Skor & Presentase \\
\hline Sangat Setuju & 4 & 27 & 108 & $87,1 \%$ \\
\hline Setuju & 3 & 4 & 12 & $12,9 \%$ \\
\hline Tidak Setuju & 2 & 0 & 0 & $0,0 \%$ \\
\hline $\begin{array}{l}\text { Sangat Tidak } \\
\text { Setuju }\end{array}$ & 1 & 0 & 0 & $0,0 \%$ \\
\hline Jumlah & 31 & 110 & $100 \%$ \\
\hline
\end{tabular}

Berdasarkan Tabel 4.6 menunjukan bahwa perolehan persentase dari 31 responden diperoleh skor jawaban dengan rincian sebagai berikut: sebanyak 27 responden $(87,1 \%)$ menyatakan sangat setuju, dan sebanyak 1 responden (12.9\%) menyatakan, serta tidak ada responden yang menyatakan tidak setuju dan sangat tidak setuju. Sehingga dapat disimpulkan bahwa aparatur desa dalam layanan keluhan masyarakat untuk memberikan kepercayaan kepada bawahannya dalam melaksanakan tugas untuk masyarakat adalah 77,77 atau dalam kategori baik. 


$\begin{array}{ll}\text { Volume } & : 04 \\ \text { Nomor } & : 03 \\ \text { Bulan } & : \text { September } \\ \text { Tahun } & : 2018 \\ \text { http } & : / / \text { ejurnal.pps.ung.ac.id/index.php/AKSARA/index }\end{array}$

Tabel 4.7 Layanan berbentuk perbuatan

\begin{tabular}{|l|l|l|l|l|}
\hline Kualifikasi & $\begin{array}{l}\text { Bobot } \\
\text { skor }\end{array}$ & Frekuensi & Skor & Presentase \\
\hline Sangat Setuju & 4 & 24 & 108 & $77,4 \%$ \\
\hline Setuju & 3 & 7 & 21 & $22,6 \%$ \\
\hline Tidak Setuju & 2 & 0 & 0 & $0,00 \%$ \\
\hline $\begin{array}{l}\text { Sangat Tidak } \\
\text { Setuju }\end{array}$ & 1 & 0 & 0 & $0,00 \%$ \\
\hline Jumlah & & 31 & 120 & $100 \%$ \\
\hline
\end{tabular}

Berdasarkan Tabel 4.7 menunjukan bahwa perolehan persentase dari 31 responden diperoleh skor jawaban dengan rincian sebagai berikut: sebanyak 24 responden $(77,4 \%)$ menyatakan sangat setuju, dan sebanyak 7 responden $(22,6 \%)$ menyatakan, serta tidak ada responden yang menyatakan tidak setuju dan sangat tidak setuju. Sehingga dapat disimpulkan bahwa layanan dalam bentuk perbuatan oleh aparatur desa dapat membantu masyarakat berupa petunjuk apabila ada kesalahan dalam tugas adalah 77,77 atau dalam kategori baik.

2) Akuntabilitas dalam pelayanan dibidang administrasi

Tabel 4.8 Tertib Administrasi

\begin{tabular}{|l|l|l|l|l|}
\hline Kualifikasi & $\begin{array}{l}\text { Bobot } \\
\text { skor }\end{array}$ & Frekuensi & Skor & Presentase \\
\hline $\begin{array}{l}\text { Sangat } \\
\text { Setuju }\end{array}$ & 4 & 0 & 0 & $0,00 \%$ \\
\hline Setuju & 3 & 0 & 0 & $0,00 \%$ \\
\hline Tidak Setuju & 2 & 13 & 26 & $41,9 \%$ \\
\hline $\begin{array}{l}\text { Sangat Tidak } \\
\text { Setuju }\end{array}$ & 1 & 18 & 18 & $58,1 \%$ \\
\hline \multicolumn{2}{r}{ Jumlah } & 31 & 54 & $10 \%$ \\
\hline
\end{tabular}

Berdasarkan Tabel 4.8 tersebut menunjukan bahwa perolehan persentase dari 31 responden diperoleh skor jawaban dengan rincian sebagai berikut: sebanyak 13 responden $(41,9 \%)$ menyatakan setuju dan sebanyak 18 responden $(58,1 \%)$ menyatakan sangat tidak setuju dan tidak ada responden yang menyatakan sangat setuju dan setuju. Sehingga dapat disimpulkan bahwa tertib admnistrasi akuntabilitas dalam pelayanan bidang administrasi menunjukkan kepada masyarakat kinerja yang harus dicapai tidak normal adalah 39,52 termasuk dalam kategori cukup baik.

\section{Pembahasan}

Dari Hasil penelitian menunjukkan bahwa dari ketiga indicator kinerja, yaitu;

1) produktivitas, belum cukup baik, (dapat dilihat dalam kurangnya memberikan pelayanan kepada masyarakat, dengan sub indikator disiplin kerja, etos kerja dan tanggungjawab kerja yang dijawab responden berada pada kategori rendah, yaitu 65\%). Berdasarkan pendapat Handoko, (2001: 92) mengemukakan bahwa perencanaan strategik sering menjadi titik permulaan bagi pemahaman dan penilaian kegiatan-kegiatan manajer dan organisasi, dalam artian bahwa produktivitas aparatur desa untuk masyarakat dapat direncanakan melalui; 


$\begin{array}{ll}\text { Volume } & : 04 \\ \text { Nomor } & : 03 \\ \text { Bulan } & : \text { September } \\ \text { Tahun } & : 2018 \\ \text { http } & : / / \text { ejurnal.pps.ung.ac.id/index.php/AKSARA/index }\end{array}$

perencanaan, terorganisir, dapat menggerakkan karakteristik masyarakat dan dapat mengkontrol kebutuhan masyarakat. Strategi yang dapat digunakan dalam mengupayakan pengelolaan sumber daya yang ada dalam rangka optimalisasi penerapan manajemen pemerintahan desa/ kalurahan adalah: a) Membuat perencanaan program, koordinasi program, pengendalian program, dan evaluasi program yang dapat mendorong pengelolaan sumber daya yang ada. Dalam hal ini, peran swadaya masyarakat dikembangkan di dalam pembangunan desa/ kalurahan. Pemerintah desa/ kalurahan mampu mengangkat martabat masyarakat desa sebagai subjek pembangunan. b) Peningkatan tingkat pendapatan masyarakatnya dengan melalui program P2KP, UED, koperasi desa, dan lain-lain. c) Menjalin kemitraan dengan investor untuk mendayagunakan potensi sumber daya alam di desa/ kalurahan. Strategi yang digunakan untuk implementasi manajemen pemerintahan desa/ kalurahan adalah: a). Menjalankan proses otonomi pemerintahan desa dan kelurahan. b). Melakukan koordinasi dengan pemerintah daerah yang ada untuk lebih cepat mengakses informasi yang ada. c). Mengubah pola kepemimpinan yang ada menjadi pola kepemimpinan partisipasif dan demokratis dengan berbasis pada budaya setempat.. d). Pengelolaan perangkat desa yang perlu ditingkatkan oleh kepala desa/ lurah untuk memaksimalkan potensi yang dimilikinya.

2) Kualitas layanan sudah cukup baik (dapat ditunjukkan dengan adanya komunikasi, kecakapan/kehandalan, keramahan, dan ketepatan waktu aparat desa dalam melayani masyarakat, melalui tanggapan respon masyarakat berada pada kategori baik, yaitu 78\%). Hal ini sesuai dengan Menurut Islamy, (2002) ada empat macam strategi yang bisa dipakai untuk menyusun strategi dalam memberikan pelayanan pada masyarakat; a) Growth Strategies (Strategi Pertumbuhan), b) Retrenchment Strategies (Strategi Meningkatkan Efisiensi), Stability Strategies (Strategi Stabilisasi). c) Collaborative Strategies (Strategi Kolaborasi), d) Profitability, setiap jenis, produk. kualitas layanan dapat dilaksanakan melalui Pentingnya Pelayanan Prima: Menurut Carol G; 2005, Pelayanan prima mempunyai peranan penting dalam pertanahan, untuk gerakan aksi dari sisi pelanggan internal maupun pelanggan eksternal, karena sangat berpengaruh pada loyalitas pelanggan kepada lembaga instansinya. Demikian juga jika pelayanan prima ini dilakukan oleh pihak non-komersil atau organisasi lainnya.

3) Akuntabilitas dalam pelayanan dibidang administrasi untuk masyarakat, berada di kategori cukup baik, hal ini dilihat pada jawaban resoponden untuk integritas rendah, penerapan standar pelayanan dibidang admnistrasi kependudukan, belum cukup baik dilihat dari pelaksanaan aturan dan norma serta etika pelayanan kepada masyarakat, serta pada tertib admnistrasi dan transparansi pelaporan akuntabilitasnya, dalam penelitian Warsono, Hardi. (2009). Untuk mencapai admnistrasi yang baik dapat di pengaruhi oleh pemimpin yang dapat beraktivitas yang Networking dalam Intergovernmental Management. Idealnya akuntabilitas dari tertib admnistrasi dapat dilaksanakan melalui prioritas program kerja dari masing-masing desa/ kalurahan selalu berpedoman atas rencana operasi dan rencana strategis desa/ kalurahan. Namun implementasi hal tersebut belum dijalankan secara konsekuen, bukan programprogram yang bersifat rutinitas dari tahun ke tahun.

\section{KESIMPULAN}

Berdasarkan Hasil penelitian yang telah dilakukan, maka diperoleh bebrapa kesimpulan sebagai berikut: 1) Perolehan skor secara keseluruhan indikator Produktivitas aparatur desa untuk pelayanan admnistrasi Di Kecamatan Anggrek Kabupaten Gorontalo Utara berada pada kategori Cukup Baik. 2) Perolehan skor secara keseluruhan indikator layanan aparatur desa di kecamatan anggrek kabupaten Gorontalo sudah cukup baik pada kategori sangat efektif. 3. Perolehan skor untuk Akuntabilitas dalam pelayanan dibidang administrasi untuk masyarakat di kecamatan Anggrek Kabupaten Gorontalo Utara berada di kategori cukup baik 


$\begin{array}{ll}\text { Volume } & : 04 \\ \text { Nomor } & : 03 \\ \text { Bulan } & : \text { September } \\ \text { Tahun } & : 2018 \\ \text { http } & : / / \text { ejurnal.pps.ung.ac.id/index.php/AKSARA/index }\end{array}$

\section{DAFTAR PUSTAKA}

Amin Widjaya Tunggal. 2000. Coso-Base Auditing. Jakarta: Harvarindo

Carol G. 2005. Organizational Learning vs the learning organization : a conversation with a practitioner, The Learning Organization. Vol 12 No 4. Emerald Group

Handoko, Hani. 2001. Manajemen Edisi 2. Yogyakarta: BPFE-Yogyakarta

Handoko, T. Hani. Manajemen. Yogyakarta: PBFE, 2001

Jurnal Ilmu Administrasi dan Kebijakan Publik

Peraturan menteri dalam negeri Nomor 47 Tahun 2016 tentang Administrasi Pemerintahan Desa

Tjiptono, Fandi, 2008, Service Management: Mewujudkan Layanan Prima, Yogyakarta ; Andi Offset

Undang-Undang Nomor 6 Tahun 2014 tentang Desa

Warsono, Hardi. 2009. "Networking dalam Intergovernmental Management". 